Saudi Journal of Medicine

Abbreviated Key Title: Saudi J Med ISSN 2518-3389 (Print) |ISSN 2518-3397 (Online) Scholars Middle East Publishers, Dubai, United Arab Emirates Journal homepage: https://saudijournals.com

Review Article

\title{
Muhammad Ali Sadpara an Anonymous Prince of the Mountains
}

\author{
Anwar Ali $^{1 *}$, Munir Ahmed ${ }^{2}$ and Ahmed Bostani ${ }^{3}$
}

${ }^{1}$ Dr. Anwar Ali, PhD-Public Health and Preventive Medicine, Hunan Provincial Key Laboratory of Clinical Epidemiology, Central South University, Changsha City, Hunan, China

${ }^{2}$ Mr. Munir Ahmed, MPhil Scholar, Department of Food Science and Engineering, Yangzhou University, Yangzhou City, Jiangsu Province, China

${ }^{3}$ Mr. Ahmed Bostani, MPhil Scholar, Department of Tourism Management, Dongbei University of Finance and Economics, Dalian City, Liaoning Province, China

DOI: $10.36348 /$ sjm.2021.v06i02.004

| Received: 02.02.2021 | Accepted: 17.02.2021 | Published: 27.02.2021

*Corresponding Author: Anwar Ali

\section{Abstract}

Mountaineering is a field that is easy to see but very difficult, those who adopt this field are well aware that one day they may not be able to see the next day's sun. It is also very attractive in the background of how dangerous it looks. The beauty of the mountain valleys can only be appreciated by one who has seen it up close and Muhammad Ali Sadpara was one of those lucky people. He was the prince of the mountains who hoisted the flag of his nation on the highest peaks of the world. He climbed eight of 14 Eight-thousanders. His first climb was Gasherbrum II in Karakoram. In this review we tried to explore the life of a mountaineer who sacrificed his life just for the sake of his nation and country. We highlighted his achievements for Pakistan. February 4th 2021 he set out for the top of the K2 Mountain with two of his team members and got lost somewhere in the valley of the hill. A rescue mission with two army helicopters was organized but no trace of them has been found. We will not consider him past because he will live in our hearts forever and ever.

Keywords: Muhammad Ali Sadpara; Mountaineer; K2 Mountain; Pakistan Tourism.

Copyright $\odot 2021$ The Author(s): This is an open-access article distributed under the terms of the Creative Commons Attribution 4.0 International License (CC BY-NC 4.0) which permits unrestricted use, distribution, and reproduction in any medium for non-commercial use provided the original author and source are credited.

\section{INTRODUCTION}

Technically anybody could walk to the top of a mountain but this would not make them a mountaineer. It takes a lot of passion and a lot of dedication to be a mountaineer. Mountaineering often involves a whole spectrum of emotions and sometimes they can all collide at once! Words cannot describe the sense of freedom you get when you are ascending a mountain. It is truly a spiritual experience leaving you feeling really alive! On any ascent there will be good times and bad times too, that's what makes the sport so personally challenging and character building. Although life of mountaineers is very tough but they are very big at heart. The highest mountains of the world where it is impossible for a man to even think, they leave their footprints there. The love between them and the mountains is very interesting. Sometimes they promise to return to these mountains and sometimes these mountains hold them to its bosom and they become an anonymous story.

$\mathrm{K} 2$, at 8,611 metres $(28,251 \mathrm{ft})$ above sea level, is the second-highest peak on Earth, after Mount
Everest at 8,848 metres $(29,029 \mathrm{ft})$. It is located in the disputed territories of the China-Pakistan border between the Baltistan zone in Gilgit-Baltistan and the Dafdar Township in the Taxkorgan Tajik Autonomous County of Xinjiang, China [1]. K2 also became popularly known as the Savage Mountain after George Bell—a climber on the 1953 American Expedition told reporters, "It's a savage mountain that tries to kill you." [2] Of the five highest mountains in the world, $\mathrm{K} 2$ is the deadliest; roughly one person dies on the mountain for every four who hit the summit $[1,3]$.

One of K2's other and theoretically less true nicknames were "The King of Mountains" and "The Mountaineers' Mountain" as well as the "Mountains of the Moon" after famous Italian climber Reinhold Messner named his book about K2 the same. GilgitBaltistan, a mountainous area of Pakistan, has more than 20 peaks of over 6,100 meters $(20,000 \mathrm{ft})$, including $\mathrm{K}-2$, the second highest mountain on Earth. Go to Gilgit Baltistan and bing the peaks above 6,100 meters. The residents of Gilgit and Gilgit Baltistan are born mountaineers and athletes. People with this body trait are flexible and will be able to trek and scale 
mountains. A normal workout will contribute to a more vigorous physical exercise.

\section{Muhammad Ali Sadpara}

Muhammad Ali Sadpara is also an anonymous prince of a similar story. He was born on $2^{\text {nd }}$ February 1976 in a village in Pakistan called Sadpara [4]. His ancestors were also involved in the same field of mountaineering. Seeing his loved ones, he also became interested in this field and that interest became obsession. He loved his country very much and one day he decided that he would fly the flag of his country at every high place in the world which is impossible for nearly everyone [5]. His passion and love led him to many successes.

In 2015 his team tried to scale the Nanga Parbat in winter and was unsuccessful. They again tried in 2016 and summited the peak, and this resulted in the first ever winter summit of Nanga Parbat. He has climbed Nanga Parbat four times. In January 2018, Ali Sadpara teamed up with Alex Txikon, a Basque mountaineer, and tried unsuccessfully to summit Mount Everest in winter without any supplemental oxygen. In June 2018, he was enlisted by speed climber Marc Batard to undertake a five year program entitled "Beyond Mount Everest". They plan to summit Nanga Parbat, K2 and Mount Everest in 2019, 2021 and 2022 respectively. He was part of the team that successfully achieved the first ever winter summit on Nanga Parbat in 2016. Both his teammates, Alex Txikon and Simone Moro, have gone on record stating that they could not have done it without Sadpara's brilliance. He had successfully climbed four eight-thousanders in a calendar year and a total of eight in his career [6]. His village Sadpara also produced many other diamonds like him. Hassan Sadpara and Nisar Sadpara were also from the same village [7].

Now it seems that the intensity of the mountains and their love for him had increased. On this side, the spirit of the country was also full in his heart. That is why he could not resist the call of the mountains and bowed his head and walked away at the call of the mountains with the flag of the country with his heart.

Sadpara and his son, Sajid Sadpara, who had climbed K2 in 2019, teamed up with Icelandic mountaineer John Snorri and Chilean mountaineer Juan Pablo, leaving the highest camp on the evening of February 4th 2021. Sajid had to come back because of a technical issue leaving the others at the Bottleneck, close to the summit. His father, Snorri and Mohr kept climbing up, but they didn't come back by night as planned. A rescue mission with two army helicopters was organized on February $6^{\text {th }}$ and $7^{\text {th }}$ [8]. Everyone is aware of this fact of life but every child of the nation, every old man and every young was hoping that maybe a miracle will happen somewhere but that did not happen.

As time goes on, it seems that maybe another love story has been added between mountains and the mountaineers. And now the prince of this story is Muhammad Ali Sadpara.

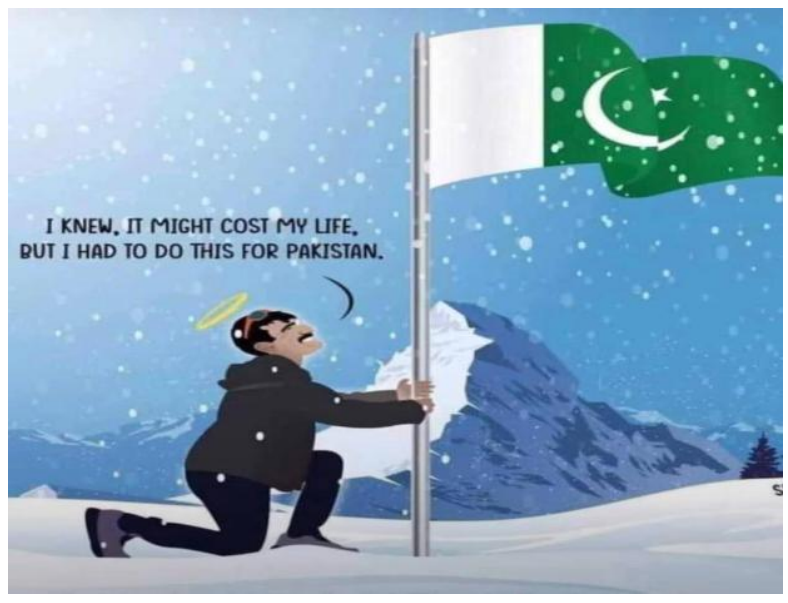

\section{REFERENCES}

1. Wikipedia. (2021). K2. Availabe online: https://en.wikipedia.org/wiki/K2 (accessed on 1 February, 2021).

2. Wikiwand. (2021). K2 Availabe online: https://www.wikiwand.com/en/K2 (accessed on 15 February, 2021).

3. Magazine, B.C. (2017). K2: THE KING OF MOUNTAINS. Availabe online:

https://basecampmagazine.com/2017/02/08/k2-theking-of-mountains/ (accessed on 12 May, 2017).

4. Alpinist. (2019). Muhammad Ali of Sadpara. Availabe online:

http://www.alpinist.com/doc/web19s/wfeature-a64tcl-muhammad-ali-sadpara (accessed on 02 May, 2019).

5. Tribune, T.E. (2017). Ali Sadpara set to hoist Pakistan's Flag on Mount Everest. Availabe online: https://tribune.com.pk/story/1589926/1-ali-sadparaset-hoist-pakistans-flag-mount-everest (accessed on 22 December, 2017).

6. News, T. (2019). Ali Sadpara becomes first Pakistani to conquer world's seven $8000 \mathrm{~m}$ peaks. Availabe online:

https://www.thenews.com.pk/latest/475728-alisadpara-becomes-first-pakistani-to-conquer-worlds-seven-8000m-peaks (accessed on May 24, 2019).

7. Wikipedia. (20121). Hassan Sadpara. Availabe online:

https://en.wikipedia.org/wiki/Hassan_Sadpara (accessed on 13 January, 2021).

8. News, D. (2021). No contact with Sadpara, two others on K2 mission. Availabe online: https://en.wikipedia.org/wiki/Ali_Sadpara (accessed on 10 February, 2021). 